\title{
QUALITY OF TROPICAL HARDWOOD FLOORS
}

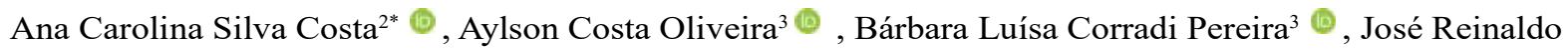 \\ Moreira da Silva ${ }^{+}$, Mônica Bezerra de Oliveira ${ }^{5}$ and Carolina Nogueira Xavier ${ }^{5}$ (b)
}

\footnotetext{
${ }^{1}$ Received on 05.12.2019 accepted for publication on 14.04.2020.

${ }^{2}$ Universidade Federal de Mato Grosso, Programa de Pós-Graduação em Ciências Florestais e Ambientais, Cuiabá, MT - Brasil. E-mail: $<$ cstanacarolina@hotmail.com>.

${ }^{3}$ Universidade Federal de Mato Grosso, Faculdade de Engenharia Florestal, Cuiabá, MT - Brasil. E-mail: <aylsoncosta@gmail.com> and $<$ babicorradi@gmail.com>.

${ }^{4}$ Universidade Federal de Lavras, Departamento de Ciências Florestais, Lavras, MG - Brasil. E-mail: <jreinaldoms@gmail.com> .

${ }^{5}$ Universidade Federal de Lavras, Programa de Pós-Graduação em Ciência e Tecnologia da Madeira, Lavras, MG - Brasil. E-mail: $<$ m.bezerradeoliveira@gmail.com>and <ncarolx@gmail.com>.

*Corresponding author.
}

\begin{abstract}
This study aimed to determine the basic density of the wood and to simulate the performance of flooring produced with wood from five tropical species: Dipteryx odorata (Cumaru), Handroanthus spp. (Ipê), Hymenaea Courbaril (Jatobá), Astronium Lecointei (Muiracatiara), and Bowdichia virgilioides (SucupiraPreta). Falling steel sphere, static and dynamic friction, indentation caused by loads applied in small areas, rolling load, and abrasiveness impact tests were simulated. The results were subjected to analysis of variance and Tukey's test at 5\% significance, and Pearson's correlation was performed between the basic density and the indexes of each flooring. The basic density of the wood flooring made from the evaluated species ranged from 0.735 to $0.958 \mathrm{g.cm}^{-3}$. D. odorata, Handroanthus spp. and H. courbaril woods were classified as heavy, while those of $A$. Lecointei and $B$. Virgilioides as moderately heavy. It was possible to indicate D. odorata, Handroanthus spp., H. courbaril, and B. Virgilioides flooring for environments with intense traffic where there is dragging or falling objects such as industries and companies. The A. Lecointei flooring can be used in residential environments with light traffic, where the loads exerted are low. There was a correlation between the basic wood density and the flooring use simulation tests.
\end{abstract}

Keywords: Tropical species; Mechanical tests; Basic density.

\section{QUALIDADE DE PISOS MACIÇOS DE MADEIRAS TROPICAIS}

RESUMO - O objetivo deste estudo foi determinar a densidade básica da madeira e simular o comportamento em uso de pisos maciços produzidos com madeiras de cinco espécies tropicais: Dipteryx odorata (cumaru), Handroanthus spp. (ipê), Hymenaea courbaril (jatobá), Astronium lecointei (muiracatiara) e Bowdichia virgilioides (sucupira-preta). Nos testes de simulação foram realizados os ensaios de impacto da esfera de aço cadente, de atrito estático e dinâmico, de endentação causada por cargas aplicadas em pequenas áreas, de carga rolante e de abrasividade. Os resultados foram submetidos à análise de variância e ao teste de Tukey, a $5 \%$ de significância, e realizou-se a correlação de Pearson entre a densidade básica e os índices de cada ensaio de simulação de pisos. A densidade básica dos pisos de madeira das espécies avaliadas variou de 0,735 a 0,958 $\mathrm{g} \cdot \mathrm{cm}^{-3}$, sendo as madeiras de D. odorata, Handroanthus spp. e H. courbaril classificadas como pesadas e as de A. lecointei e B. virgilioides como moderadamente pesadas. Foi possivel indicar os pisos de D. odorata, Handroanthus spp., $\boldsymbol{H}$. courbaril e $\boldsymbol{B}$. virgilioides para ambientes com tráfego intenso, onde há o arraste ou a queda de objetos, como indústrias e empresas. Já o piso de A. lecointei pode ser utilizado em ambientes residenciais, com tráfego leve, onde as cargas exercidas sejam baixas. Houve correlação entre a densidade básica da madeira e os ensaios de simulação dos pisos em uso.

Palavras-Chave: Espécies tropicais; Ensaios mecânicos; Densidade básica. 


\section{INTRODUCTION}

Wood is used prominently in the manufacture of higher value-added products (PMVAs) such as doors, frames, floors, and furniture, among others. Hardwood floors are widely used in residential, commercial and industrial environments with the aim of improving the appearance of surfaces, in addition to offering thermal and acoustic comfort (ANPM, 2015). Rocha et al. (2014) emphasize that wood is a durable and resistant material, and it is synonymous with comfort and warmth when used for floor production, which makes it highly appreciated.

The physical and mechanical properties and aesthetic attributes should be evaluated to select the species to be used for producing flooring. The density of wood is one of the main factors to be considered in the selection of raw material, because dense woods result in more resistant floors (Padilha et al., 2006; Rocha et al., 2014; Blanco et al., 2015). Tropical species are the most used in flooring production (Oliveira et al., 2019) because they have higher densities and different combinations of colors and designs.

Flooring should be suitable for use and the environment where it will be inserted, therefore aesthetics, quality, economy and safety should be considered. It is noteworthy that wood flooring is subject to risks when in use such as damage due to objects falling, wear by abrasive elements, wear by people traffic, dragging of objects, among others (Blanco et al., 2015), which visibly affects its aesthetics.

Faced with the difficulty of evaluating the mechanical performance of wood floors in the long term, tests which simulate the performance in use are used to evaluate and ensure their quality, obtain information for their best use and also to assist in the choice of raw material. According to Padilha et al. (2006), it is necessary to evaluate the flooring characteristics and their behavior in use to propose their proper use; this results in a differential in the market whether to add value to the final product, or to ensure the quality of the product to the consumer.

In this sense, wood flooring use simulation tests are an important tool to evaluate their behavior. They also make it possible to select tropical species which have quality for flooring production or to indicate their best use. Therefore, the objectives of this study were to determine the behavior in use of the most commercialized tropical species flooring by the companies in Mato Grosso and to evaluate the correlation between basic wood density and flooring quality.

\section{MATERIAL AND METHODS}

Solid hardwood floor tiles were provided by the Company Brasil Tropical Pisos, located in the city of Alta Floresta, Mato Grosso. Wood flooring made from five tropical species were used: Dypteryx odorata (Aubl.) Willd (Cumaru), Handroanthus spp. (ipê), Hymeneae courbaril Linneaeus (jatobá), Astronium Lecointei Ducke (muiracatiara) and Bowdichia virgilioides Kunth (sucupira-preta).

A total of 50 floor pieces with the dimensions 12.7 $\times 27.9 \times 2 \mathrm{~cm}$ were selected for each species, which is in agreement with the company's marketing standard.

\subsection{Basic density}

The basic wood density of the evaluated floors was determined according to the standard ABNT NBR 11941 (ABNT, 2003), adapted for the size of the specimens. Twenty floor samples were used for each species, totaling 100 specimens.

\subsection{Flooring use simulation tests}

\section{Preparation of specimens}

To perform the wood flooring use simulation tests, 40 flooring pieces of each species were processed to manufacture 300 specimens, in the dimensions recommended by ASTM D 2394-05 (ASTM, 2011) of $24 \times 12 \times 2 \mathrm{~cm}$, and by Martins (2008) of $9.5 \times 9.5 \times 2$ $\mathrm{cm}$, with adjustments made to the floor length, but with no change in thickness or faces.

The specimens were subsequently taken to the acclimatization chamber $\left[\mathrm{T}=(20 \pm 2){ }^{\circ} \mathrm{C}\right.$ and $\mathrm{UR}=$ $(65 \pm 5) \%$, with the purpose of keeping them with equilibrium humidity equal to $12 \%$ to perform the flooring use simulation tests. The specimens did not receive any finishing products.

The following tests were performed according to ASTM D 2394-05 (ASTM, 2011): impact of falling ball, static and dynamic friction, floor surface, indentation from small area loads, and rolling load. For the first, 100 samples were used per treatment and for the others, 50 , all with dimensions equal to $24 \times 12 \times 2 \mathrm{~cm}$. The abrasiveness test was conducted according to Martins (2008), in 50 samples per treatment, with dimensions of $9.5 \times 9.5 \times 2 \mathrm{~cm}$.

Revista Árvore 2021;45:e4503 
The flooring of the evaluated species were grouped into classes according to the classification proposed by Oliveira et al. (2019), which established wood flooring quality classes based on mean values of the flooring use simulation tests.

\subsection{Statistical analyses}

The experiment was installed according to a completely randomized design with five treatments (species) and 50 repetitions (pieces of floors), totaling 250 sample units.

The data were submitted to the Shapiro-Wilk tests to assess the normality of the errors, and Bartlett's test to test the homogeneity of the variances. The data were transformed when they did not meet the assumptions of normality and homogeneity. Next, the results were subjected to analysis of variance (ANOVA) to verify the differences between the evaluated treatments. The Tukey test was applied at 5\% significance when there were significant differences. Pearson's correlation was conducted with the pairs of basic density values and the indexes of each flooring use simulation test.

In the steel ball shooting simulation test, the regression analysis was performed with the pairs of values from the produced indentation and the height of the ball falling, obtaining an adjustment of the first degree equation. Thus, it was possible to calculate the indentation index for the height of $180 \mathrm{~cm}$ for each evaluated species, according to the recommendation of ASTM D 2394-05 (ASTM, 2011).

Statistical analyses were performed using the R-3.5.1 software program (Fereira et al., 2018).

\section{RESULTS}

\subsection{Basic density}

The results obtained for the basic density of the solid hardwood floors of the five evaluated species are shown in Figure 1.

The D. odorata and Handroanthus spp. wood presented the highest averages of basic density, and did not differ statistically between them. The A. lecointei and $B$. virgilioides woods showed the lowest averages and were statistically similar, while the $H$. courbaril wood differed statistically from all the others (Figure 1). The variation among all species was low, and a general coefficient of variation of $7.91 \%$ was observed.
Averages followed by the same letter do not differ statistically at $5 \%$ significance by the Tukey test.

Médias seguidas pela mesma letra não diferem estatisticamente a 5\% de significância, pelo teste Tukey.

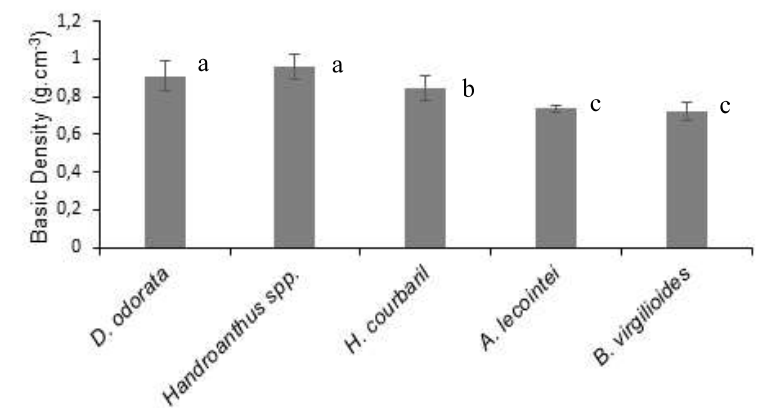

Figure 1 - Mean values and standard deviation of the basic density $\left(\mathrm{g} . \mathrm{cm}^{-3}\right)$ for the evaluated wood floors

Figura 1 -Valores médios e desvio-padrão da densidade básica $\left(\right.$ g. $\left.\mathrm{cm}^{-3}\right)$ para os pisos das madeiras avaliadas.

\subsection{Flooring use simulation tests}

\section{Falling ball impact test}

The relationship between the depression caused by the impact of the steel ball and the heights of fall on the solid hardwood floors of the five evaluated species are shown in Figure 2.

It was found that the release of the steel ball on the surface of the floor caused deformation for all species; as verified by Blanco et al. (2015), with the increase in the ball release distance, the greater the depression (Figure 2).

The mean indentation index calculated for the height of $180 \mathrm{~cm}$ for the D. odorata wood was equal to 0.195 , while for Handroanthus spp. it was 0.184 , for $H$. courbaril 0.316 , for $A$. lecointei 0.339 , and for $B$. virgilioides 0.468 .

\subsection{Static and dynamic friction tests}

Figure 3 a shows the mean values for the coefficients of static friction and dynamic friction for the solid hardwood flooring of the five evaluated species.

There was no significant difference between the averages of the static friction test for the wood flooring of the different species, presenting a variation of $22.44 \%$ between the highest and lowest mean value observed.

The mean dynamic friction coefficient showed a significant difference, with the highest mean value for the $D$. odorata (0.323) flooring, and the lowest value for $A$. lecointei (0.130). The Handroanthus spp., H. courbaril and $B$. virgilioides woods were statistically similar. 

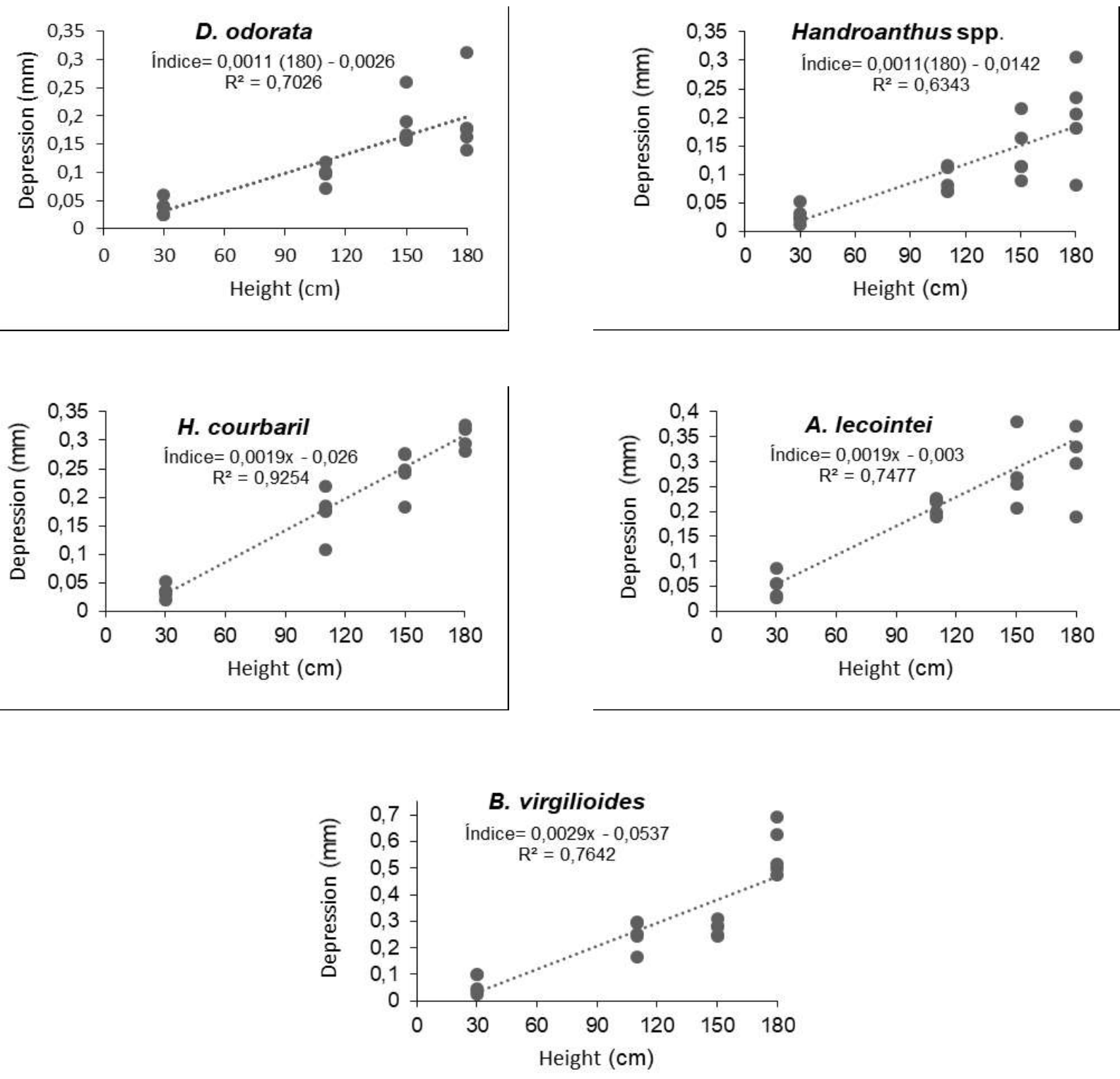

Figure 2 - Relationship between depression caused by the steel ball fall and the falling heights for the floors of the evaluated woods. Figura 2 - Relação entre a depressão causada pela queda da esfera de aço e as alturas de queda para os pisos das madeiras avaliadas.

\subsection{Floor surface indentation from small area loads}

Figure $3 b$ shows the results obtained for the indentation of loads applied in small areas test after 50 and 100 cycles for the solid wood flooring of the five evaluated species.

The D. odorata, Handroanthus spp. and H. courbaril wood flooring presented the lowest mean values with the application of loads in small areas in all cycles, which indicates greater resistance of the floors due to the lower depression. The A. lecointei wood presented the highest mean value, and therefore it was considered the least resistant, differing statistically from the others. With the exception of the hardwood A. lecointei flooring, all the evaluated woods were considered similar to each other according to the Tukey test at 5\% significance (Figure $3 b$ ).

Revista Árvore 2021;45:e4503 
Averages followed by the same letter do not differ statistically at $5 \%$ significance by the Tukey test.

Médias seguidas pela mesma letra não diferem estatisticamente a $5 \%$ de significância, pelo teste de Tukey.
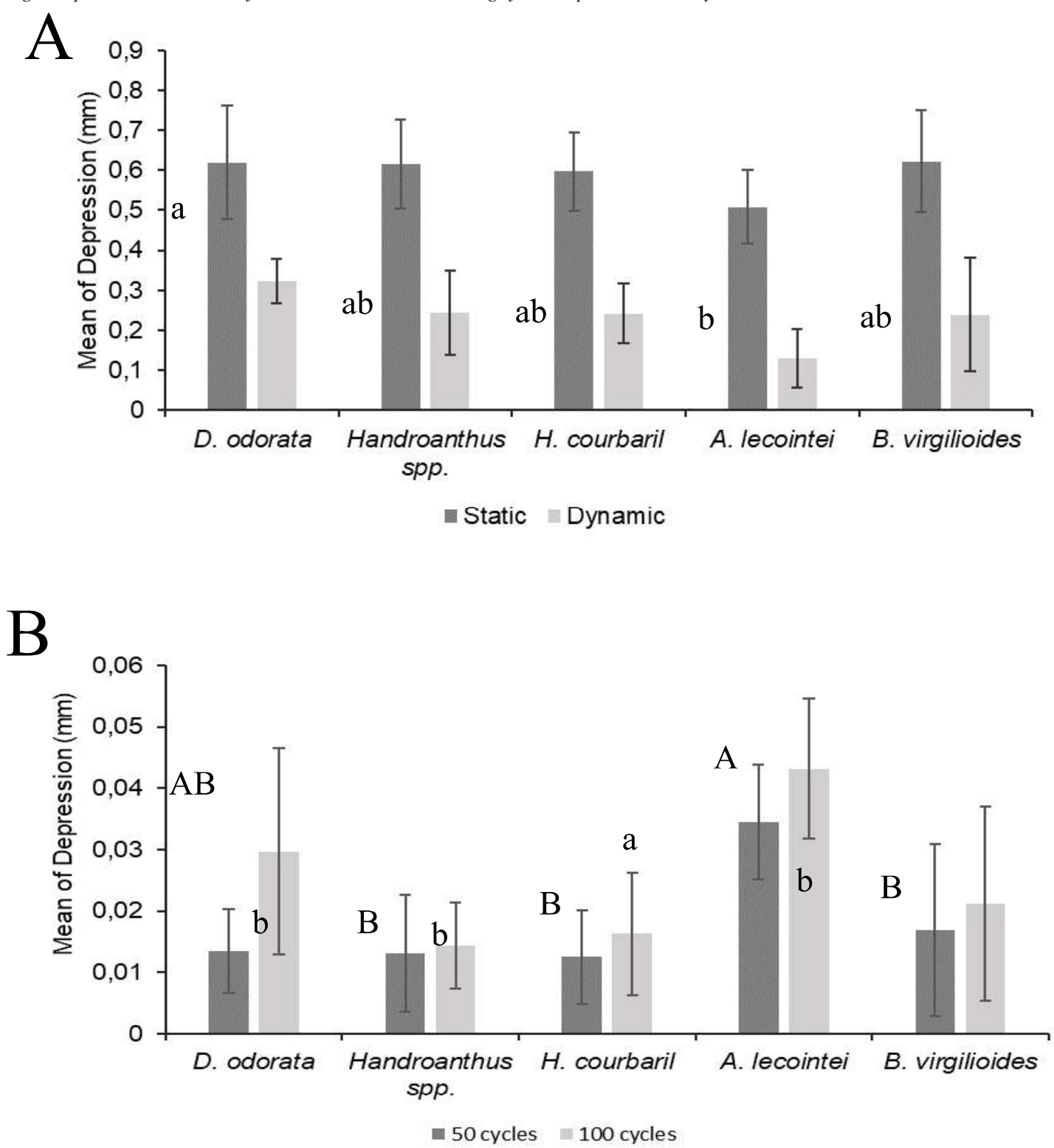

Figure 3-a - Mean values and standard deviation of the static and dynamic friction coefficients for the evaluated wood floors. b - Mean values and standard deviation of the indentations caused by loads applied after 50 and 100 cycles in small areas for the evaluated wood floors.

Figura $3-a$ - Valores médios e desvio-padrão dos coeficientes de atrito estático e dinâmico para os pisos das madeiras avaliadas. b - Valores médios e desvio-padrão das endentações causadas por cargas aplicadas após 50 e 100 ciclos em pequenas áreas para os pisos das madeiras avaliadas.

\subsection{Rolling load test}

Table 1 shows the results obtained for the rolling load test after 10, 25 and 50 cycles for the solid wood flooring of the five evaluated species.
The D. odorata, Handroanthus spp. and H. courbaril hardwood floors showed greater resistance to dragging of objects, because they presented the lowest averages of the depressions obtained in the rolling load test, and did not differ statistically among each other in all cycles (Table 1).

Revista Árvore 2021;45:e4503 
Table 1 - Mean values of depressions caused in the rolling load test for the wood floors evaluated.

Tabela 1 - Valores médios das depressões causadas no ensaio de carga rolante para os pisos das madeiras avaliadas.

\begin{tabular}{lccr}
\hline \multirow{2}{*}{ Species } & \multicolumn{3}{c}{ Mean of Depression $(\mathrm{mm})$} \\
\cline { 2 - 4 } & 10 cycles & 25 cycles & 50 cycles \\
\hline D. odorata & $0.042 \mathrm{~b}$ & $0.058 \mathrm{~b}$ & $0.075 \mathrm{~b}$ \\
Handroanthus spp. & $0.035 \mathrm{~b}$ & $0.063 \mathrm{~b}$ & $0.079 \mathrm{~b}$ \\
H. courbaril & $0.056 \mathrm{~b}$ & $0.068 \mathrm{~b}$ & $0.077 \mathrm{~b}$ \\
A. lecointei & $0.127 \mathrm{a}$ & $0.178 \mathrm{a}$ & $0.201 \mathrm{a}$ \\
B. virgilioides & $0.142 \mathrm{a}$ & $0.214 \mathrm{a}$ & $0.246 \mathrm{a}$ \\
\hline Averages followed by the same letter within the same column do not differ
\end{tabular}

statistically at $5 \%$ significance by the Tukey test.

Médias seguidas pela mesma letra, dentro da mesma coluna, não diferem

estatisticamente a $5 \%$ de significância, pelo teste de Tukey.

\subsection{Abrasiveness assay}

Figure 4 shows the results obtained for the abrasive test for the solid hardwood flooring of the five evaluated species.

A. lecointei hardwood flooring presented the highest mean of depression $(0.200 \mathrm{~mm})$, differing statistically from the other species, while the $D$. odorata and Handroanthus spp. flooring presented statistically similar averages for depressions. The $H$. courbaril and $B$. Virgilioides hardwood floors showed the lowest mean of depressions and were statistically similar, showing to be more resistant to wear and tear after 500 cycles of abrasion (Figure 4).

\subsection{Pearson Correlation}

The correlations between basic wood density and each floor simulation assay in use were significant for the assays: impact of falling ball tests $(-0.92 *)$, friction tests $\left(0.58^{*}\right)$, floor surface indentation $\left(-0.58^{*}\right)$ and rolling load $(-0.93 *)$.

It can be verified that only the abrasive assay of the five flooring use simulation tests performed in the present study did not show significant correlation with wood density (-0.08).

\section{DISCUSSION}

\subsection{Basic density}

The D. odorata, Handroanthus spp. and $H$. courbaril woods were classified as heavy, while the $A$. lecointe $i$ and $B$. virgilioides woods were classified as moderately heavy, according to Rocha et al. (2014), who elaborated a classification regarding the basic density of wood for use in paving.
Averages followed by the same letter do not differ statistically at $5 \%$ significance by the Tukey test.

Médias seguidas pela mesma letra não diferem estatisticamente a $5 \%$ de significância, pelo teste de Tukey.

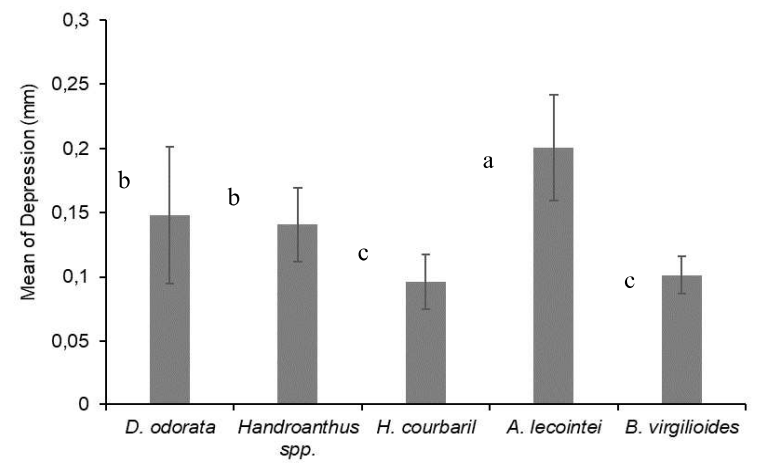

Figure 4 - Mean values and standard deviation of the depressions caused in the abrasive test for the evaluated wood floors.

Figura 4 - Valores médios e desvio-padrão das depressões causadas no ensaio de abrasividade para os pisos das madeiras avaliadas.

Values close to those found in this study were observed in the literature. In evaluating Brazilian tropical timbers, Araújo (2007) found basic wood density values equal to $0.910 \mathrm{~g} . \mathrm{cm}^{-3}$ for $D$. odorata, 0.870 g.cm $\mathrm{cm}^{-3}$ for Handroanthus spp, $0.760 \mathrm{~g} . \mathrm{cm}^{-3}$ for $H$. courbaril, $0.790 \mathrm{g.cm}^{-3}$ for A. lecointei, and $0.850 \mathrm{g.cm}-$ ${ }^{3}$ for B. virgilioides. Furthermore, Rocha et al. (2014) found basic density equal to $0.960 \mathrm{~g} . \mathrm{cm}^{-3}$ for Tabebuia impetiginosa.

Considering the results found for the basic density (Figure 1) of the woods evaluated in the present study, an emphasis on D. odorata (cumaru), Handroanthus spp (ipê) and H. courbaril (jatobá) woods are indicated for flooring production because, according to Rocha et al. (2014), timbers considered very heavy and heavy are ideal for use in floors, since they are more resistant and have greater durability over time.

\subsection{Falling ball impact test}

This index expresses that the lower its value, the better the wood resistance for this type of force. Therefore, the floors which presented higher resistance to the impact of the steel ball were D. odorata and Handroanthus spp., with values lower than 0.200.

In a study with native commercial timber for manufacturing floors, Oliveira et al. (2019) found an indentation index of 0.186 for D. odorata flooring, 0.241 for Tabebuia impetiginosa and 0.390 for Bowdichia nitida, being similar to those observed in this study. 
D. odorata and Handroanthus spp. wood presented the lowest indentation indexes and had the highest density (Figure 1). In contrast, $B$. virgilioides presented the highest indentation index, and had the lowest density (Figure 1).

Blanco et al. (2015) worked with Tectona grandis medium density wood of $0.540 \mathrm{~g} . \mathrm{cm}^{-3}$ and found a mean value equal to 0.490 for the indentation index, being higher than that observed for the flooring of all the species evaluated in this study. The higher indentation index is related to lower density of the $T$. grandis wood compared to the tropical species of this study.

According to the classification of Oliveira et al. (2019) in considering the shooting steel ball test, the $D$. odorata and Handroanthus spp. wood floors fall into the high quality class $(<0.180)$, while the $H$. courbaril, $A$. lecointei and $B$. virgilioides floors are classified as low quality $(>0.301)$. Therefore, as the impact resistance to the steel ball was low for $H$. courbaril, A. lecointei and $B$. virgilioides, it is necessary to protect the flooring of these woods from eventual object falls to avoid further deformation and damage.

\subsection{Static and dynamic friction assay}

Lower static coefficient values indicate that the surface is smoother and less force is needed to initiate movement on the floor. In practical terms, this fact represents the slip resistance.

A lower value for the dynamic friction coefficient indicates less force required for the continuity of the movement. Therefore, the D. odorata flooring was considered the least slippery, which constitutes a safety factor in the risk of people falling during traffic.

It is important to mention that the specimens did not receive any finishing products, and were only sanded. Therefore, the coefficients of friction found represent the superficial resistance of natural wood.

Oliveira et al. (2019) found static and dynamic friction coefficients equal to 0.253 and 0.175 for $D$. odorata wood floors, respectively; mean values of 0.269 and 0.198 for T. impetiginosa (ipê) wood flooring; and 0.254 and 0.173 for $B$. nitida (sucupira) wood flooring. These values were lower than those observed for the same species in the present study due to a layer of varnish that the specimens received.

In evaluating hardwood floors of different Eucalyptus urophylla clones, Padilha et al. (2006) found static and dynamic friction coefficient values equal to 0.376 and 0.230 , respectively. In addition, Martins et al. (2013) found static and dynamic friction coefficient values for Eucalyptus floors equal to 0.250 and 0.150 , respectively. In studying $T$. grandis wood, Blanco et al. (2015) observed a value of 0.370 for static friction and 0.180 for dynamic friction. The values found in the cited studies were lower than those observed in the present study with tropical species.

According to the classification proposed by Oliveira et al. (2019), D. odorata, Handroanthus spp., H. courbaril and $B$. virgilioides hardwood floors were positioned in the high quality class $(>0.181)$, and $A$. lecointei hardwood flooring in the low quality class $(<0.181)$. Therefore, the result was satisfactory for D. odorata, Handroanthus spp., H. courbaril and B. virgilioides flooring, being considered ideal for use in floors.

The coefficients of friction are determinant for the choice of the wood species depending on the use and traffic of the site where the floor will be installed, and it is important that they do not provide a slippery surface. In other words, the higher the value of the friction coefficient, the less slippery and the safer the tread surface (Oliveira et al., 2019), which can help avoid falls caused by slipping and allows safe transit (Martins, 2008).

\subsection{Assay of load-filling applied in small areas}

The behavior of D. odorata, Handroanthus spp. and $H$. courbaril woods, classified as heavy by their basic density (Figure 1), occurred as reported in the literature. According to Oliveira et al. (2019), high densities provide greater strength and hardness, which reflect the resistance to applied load. For the $A$. lecointe $i$ hardwood flooring, which has the smallest density (Figure 1), the depression observed in the assay was higher.

In evaluating the behavior of flooring use in simulation, the smallest difference between the depressions obtained in the first and the second measurement interval (50 and 100 cycles) was observed for the Handroanthus spp. flooring (8\%), which shows that the increase in the number of cycles did not significantly increase wear on the floors of this species. For the $H$. courbaril, A. lecointei and B. virgilioides floors, differences in depressions between 50 and 100 cycles of 30,25 and $26 \%$ were observed, respectively. In contrast, the greatest strain variation of $121 \%$ was

Revista Árvore 2021;45:e4503 
observed for the D. odorata flooring, which indicates that this flooring will present greater deformation over time of use.

Oliveira et al. (2019) found average indentation values after 100 cycles, equal to $0.016 \mathrm{~mm}$ for $B$. nitida floors (sucupira) and $0.024 \mathrm{~mm}$ for Mimosa scabrella (Amendola) floors, constituting values close to those observed for the D. odorata, Handroanthus spp., $\mathrm{H}$. courbaril and $B$. virgilioides woods evaluated in this study (Figure 3b). In contrast, the authors did not observe depressions after 100 cycles for T. impetiginosa (Ipê) or D. odorata (cumaru) wood.

Padilha et al. (2006) found indentation values for E. urophylla wood after 100 cycles of between 0.049 and $0.092 \mathrm{~mm}$; Martins et al. (2013) found values of $0.050 \mathrm{~mm}$ after 100 cycles for E. microcorys; and Blanco et al. (2015) found $0.10 \mathrm{~mm}$ of depression for T. grandis floors. In evaluating Hovenia dulcis wood for flooring production, Marchesan (2016), found $0.11 \mathrm{~mm}$ of depression after 100 cycles. The values found in the cited studies were higher than in the present study, and this difference was due to the lower density of the wood used by the aforementioned authors.

According to the classification proposed by Oliveira et al. (2019), the D. odorata, Handroanthus spp., $H$. courbaril and B. virgilioides hardwood floors were classified as intermediates (0.006-0.030) and the $A$. lecointei flooring was classified as low quality $(>0.031)$. Therefore, the resistance to indentation by loads applied in small areas was satisfactory for D. odorata, Handroanthus spp., $H$. courbaril and $B$. virgilioides hardwood flooring. These species are considered suitable for use in residential and local environments which have intense traffic of people with high heels.

\subsection{Rolling load test}

According to Marchesan (2016), the lower the depression caused in the wood, the greater its resistance will be, meaning the better its performance in relation to the efforts made against the wood flooring in use. The best obtained results of resistance may be related to higher values of basic density for the cited species (Figure 1), because the higher the wood density, the lower the depression caused in the floor.

The $A$. lecointei and B. virgilioides hardwood floors showed the highest averages of depressions and were considered statistically similar in each of the cycles. The lower results obtained for these species are related to lower basic density values (Figure 1). Therefore, the variation in the values of the depressions caused by the drag was generally inversely proportional to the variation in wood density.

The mean values obtained from depressions after 50 cycles for the wood flooring of the species evaluated in this study were lower than the average reported by other authors (Padilha et al., 2006; Santos et al., 2010; Blanco et al., 2015; Marchesan, 2016), including for $B$. virgilioides flooring, which presented inferior behavior to that of the others $(0.2460 \mathrm{~mm})$.

Oliveira et al. (2019) found mean depression values after 50 cycles equal to $0.110 \mathrm{~mm}, 0.105 \mathrm{~mm}$ and $0.205 \mathrm{~mm}$ for $D$. odorata, $T$. impetiginosa and $B$. nitida woods, respectively. These values were higher than those observed in this study for the D. odorata and Handroanthus spp. floors, and close to that observed for B. virgilioides (Table 1).

It was found that the hardwood flooring evaluated in this study showed increased deformation with the increase in the number of rolling load cycles (Table 1). However, the increase was higher in the interval of 10 and 25 cycles when compared to the range of 25 to 50 cycles.

For the D. odorata floors, the proportion of increase in depression was $38 \%$ in the range of 10 to 25 cycles and $29 \%$ in the range of 25 to 50 cycles, while the increase was 82 and $24 \%$ for the Handroanthus spp. flooring; 21 and $12 \%$ for $H$. courbaril; 40 and $13 \%$ for A. lecointei; and 51 and $14 \%$ for $B$. virgilioides. This fact is explained by the compaction suffered by wood after successive rolling load passages, which confers greater mechanical strength (Martins, 2008).

According to the quality classification of Oliveira et al. (2019), the D. odorata, Handroanthus spp. and $H$. courbaril wood floors were classified as high quality $(<0.120)$, and are therefore indicated for installation in places which receive intense traffic and frequent drag of heavy objects such as machines occurs. The $A$. lecointei and B. virgilioides floors were positioned in the intermediate quality class $(0.121-0.300)$ and are indicated for installation where traffic is not intense, as in residential environments.

\subsection{Abrasiveness assay}

High abrasion resistance of hardwood floors provide less wear, thus increasing its useful life after treading (Martins et al., 2013). 
When comparing the results of depressions obtained by abrasive assays with other potential species for flooring production, it appears that the results obtained in the present study were superior. Martins et al. (2013) found medium depressions equal to $0.055 \mathrm{~mm}, 0.073$ $\mathrm{mm}$ and $0.076 \mathrm{~mm}$ for E. Cloeziana, E. Microcorys and Corymbia maculate floors, respectively. In evaluating floors manufactured by a combination of bamboo blades and (edge-glued panels) EGP of pinus wood, CortezBarbosa et al. (2014) observed $0.080 \mathrm{~mm}$ of depression.

In evaluating $T$. grandis wood, Blanco et al. (2015) obtained $0.100 \mathrm{~mm}$ of depression in the abrasive assay, while Marchesan (2016) obtained $0.08 \mathrm{~mm}$ of depression in the abrasive assay in evaluating $H$. dulcis wood for flooring production, constituting higher results than those observed in this study.

\subsection{Pearson Correlation}

There was an inversely proportional relationship in the shooting steel ball impact test between the indentation index and wood density, which was confirmed by the strong negative correlation of -0.92 . This same correlation was verified by several authors (Martins et al., 2013; Blanco et al., 2015; Oliveira et al, 2019; Marchesan, 2016).

The static friction and dynamic friction coefficients showed a moderately positive significant correlation of 0.58 with the wood density. Thus, dense woods result in safer flooring for people traffic.

It was verified that the resistance to loads applied in small areas was affected by wood density, because there was a moderately negative significant correlation of -0.58 , which corroborates the results obtained by Blanco et al. (2015). Therefore, denser timbers result in more resistant flooring to loads applied in small areas.

In the rolling load test, the variation in the depression values caused by the drag was generally inversely proportional to the variation in the wood density, and a strong negative correlation of -0.93 was verified. The resistance to this type of effort is the result of the hardness and density of the material, with the latter being the main factor to be considered in the classification of wood uses (Blanco, 2016).

There was no significant correlation between the basic wood density and the results obtained for the abrasive assay. In performing abrasion tests in bamboo mosso (Phyllostachys pubescens) for manufacturing solid floors, Berndsen et al. (2014) determined that higher densities do not always result in greater resistance to wear. This fact corroborates the results obtained in this study, in which the wood of the $D$. odorata and Handroanthus spp. species which have the highest densities (Figure 1) did not present the greatest resistance to wear caused by the abrasive test (Figure 4).

\section{CONCLUSIONS}

The D. odorata, Handroanthus spp. and $H$. courbaril wood floors were classified as heavy, and those of $A$. lecointei and B. virgilioides as moderately heavy.

There was a significant correlation between the basic wood density and the steel ball, friction, the filling of loads applied in small areas and the rolling load impact tests.

It was possible to indicate the $D$. odorata, Handroanthus spp., H. courbaril and B. virgilioides floors for environments with intense traffic and/or where there is the drag or fall of objects, such as for industries and companies. The A. lecointei flooring can be used in residential environments with light traffic where the exerted loads are low.

\section{AUTHOR CONTRIBUTIONS}

The manuscript is part of the master's thesis of the first author. Aylson Costa Oliveira, Bárbara L. C. Pereira and José Reinaldo M. da Silva contributed to the study conception and design. Material preparation, data collection and analysis were performed by Ana Carolina Silva Costa, Mônica B. de Oliveira and Carolina N. Xavier. The first draft of the manuscript was written by Ana Carolina Silva Costa and all authors commented on previous versions of the manuscript. All authors read and approved the final manuscript.

\section{REFERENCES}

American Society for Testing and Materials. Simulated service testing of wood and wood-base finish flooring: ASTM D 2394-05. Philadelphia, 2011.

Araújo HJB. Relações funcionais entre propriedades físicas e mecânicas de madeiras tropicais brasileiras. 
Floresta. 2007; 37(3):399-416. doi: 10.5380/ rf.v37i3.9937

Associação Brasileira de Normas Técnicas. Madeira: determinação da densidade básica: NBR 11941. Rio de Janeiro, 2003.

Associação Nacional dos Produtores de Pisos de Madeira - ANPM. Guia básico para instalação de pisos de madeira. 2015 [cited 18/02/2020]. Edition 2. Available from: https://www.anpm.org.br/publicacoes/ guia-basico-para-instalacao-de-pisos-de-madeira/

Associação Nacional dos Produtores de Pisos de Madeira - ANPM. Pisos de madeira: características de espécies brasileiras. 2015 [cited 18/02/2020]. Edition 2. Available from: https://www.anpm.org.br/publicacoes/ pisos-de-madeira-caracteristicas-de-especiesbrasileiras/

Blanco-Florez J, Silva JRM, Braga PPC, Lima, JT, Trugilho PF. Simulação em serviço de pisos de madeira jovem de Tectona grandis. Revista Matéria. 2015; 20(4): 1048-1060. doi: 0.1590/S1517707620150004.0107.

Blanco-Florez, J. Comportamento em serviço da madeira jovem de Tectona grandis L.f com diferentes acabamentos para uso em ambiente externo. [tese]. Lavras, MG. Universidade Federal de Lavras; 2016.

Berndsen RS, Klitzke RJ, Batista DC, Nascimento EM, Ostapiv F. Mechanical resistance of moso bamboo (Phyllostachys pubescens) part 2: axial tensile strength, hardness and wear resistance. Floresta. 2014; 44(3):505 - 514. doi: 10.5380/rf.v44i3.33311.

Cortez-Barbosa J, Silva JRM, Alvarenga F, Souza AJD, Araújo V, Garcia JN Simulation Analysis of In-Service Bamboo and Pine EGP Composite Flooring. Advanced. doi: Materials Research, 2014; 1025-1026():233-240. doi: 10.4028/www.scientific.net/AMR.1025-1026.233.

Ferreira EB, Cavalcanti PP, Nogueira DA. R package. Version 1.2.0. ExpDes: Experimental Designs; 2018.

Marchesan R. Caracterização tecnológica da madeira de Hovenia dulcis Thunberg para fabricação de pisos. [tese]. Curitiba, PR. Universidade Federal do Paraná; 2016

Martins, M. Ensaios de simulação de uso em pisos de Eucalyptus clöeziana F. Muell, Eucalyptus microcorys F. Muell e Corymbia maculata Hook. [dissertação]. Lavras, MG. Universidade Federal de Lavras; 2008.

Martins M, Silva JRM, Lima JT, Gonçalves MTT, Filipe AP. Simulação em uso dos pisos de madeira de Eucalyptus sp. e Corymbia maculata. Cerne, 2013; 19(1):151-156. doi: 10.1590/S0104 77602013000100018 .

Oliveira MB, Hein PRG, Lima JT. The establishment of quality classes of wood floors by simulated use. Cerne. 2019; 25(1):105-109.doi: $10.1590 / 01047760201925012618$

Padilha C, Lima JT, Silva JRM, Trugilho PF, Andrade HB. Avaliação da qualidade da madeira de Eucalyptus urophylla para utilização em pisos. Scientia Forestalis. 2006; (71):141-147.

Rocha LTC, Pereira SJ, Guimarães KLM, Valporto MS, Viegas VA. Madeiras tropicais quanto à densidade $\mathrm{e}$ cor para uso em pavimentação. In: Anais do Congresso Brasileiro de Pesquisa E Desenvolvimento em Design, 2014, Gramado, RS. Gramado:2014, p. 1-10

Santos IS, Lima JT, Silva JRM. Avaliação dos pisos produzidos a partir de toras de clones de Eucalyptus $\mathrm{sp}$ com pequenos diâmetros. Cerne. 2010; 16(4):473-478. doi: 10.1590/S0104-77602010000400007. 